\title{
The mass media and tendentious modernity in the transition process from the national society to the European Community
}

\author{
Meios de comunicação de massa e modernização \\ tendenciosa no processo de transição da sociedade \\ nacional para a Comunidade Europeia
}

Constantin Schifirneț*

\begin{abstract}
This paper analyses the transformations of mass media in the process of constructing the European identity after the two enlargements. I will focus on the impact of mass communication on Europeanization. I study the transition in Romania in particular to understand Europeanization, otherwise it sounds as if my study covers the broad scope in Europe, and case study is Romanian media. My thesis is that mass media could play an active role in promoting the European integration process if it shifted its attention from reflecting historical particularities to reflecting upon the modern evolution of each EU member. I introduce the concept of tendentious modernity, useful in studying mass communication in transitional societies. In such societies, modernization began with political institutional construction and not with the building of the capitalist economy. Modernity is the framework and main element upon which a nation is supported, a mosaic however not by means of economy, the basis of a national development and progress. In these societies, such as Romania, mass media promote this mosaic modernity, and, at the same time they, acts the primary messenger of modernity and Europeanization.
\end{abstract}

Keywords: Europeanization; Mass media; Modernity; Tendentious modernity

Resumo: Este artigo analisa as transformações dos meios de comunicação de massa no processo de construção de identidade europeia após as duas ampliações. Irei me concentrar no impacto dos meios de comunicação de massa na europeização. Estudo a transição na Romênia em particular para entender a europeização, do contrário parece como se meu estudo cobrisse toda a Europa, e os meios de comunicação na Romênia. Minha tese é que os meios de comunicação poderiam exercer um papel ativo na promoção do processo de integração europeia caso mudasse sua atenção das particularidades

* Faculty of Communication and Public Relations, National School of Political Sciences and Administrative Studies, Bucuresti, Romania; e-mail: cschifirnet@yahoo.com

\begin{tabular}{|c|c|c|c|c|c|}
\hline Civitas & Porto Alegre & v. 9 & n. 1 & p. 50-64 & jan.-abr. 2009 \\
\hline
\end{tabular}


históricas para a evolução moderna de cada país-membro da UE. Introduzo o conceito de modernidade tendenciosa, útil para estudar meios de comunicação de massa em sociedades em transição. Nessas sociedades a modernização começou com a construção de instituições políticas e não com a construção da economia capitalista. Modernidade é o principal arcabouço e principal elemento sobre o qual se apóia uma sociedade, um mosaico, entretanto por meio da economia, a base de um desenvolvimento nacional e do progresso. Nestas sociedades, como a Romênia, meios de comunicação de massa promovem este mosaico de modernidade e ao mesmo tempo atuam como mensageiros de modernidade e europeização.

Palavras-chave: Europeização; Meios de comunicação de massa; Modernidade; Modernidade tendenciosa

\section{Introduction}

For the first part, I will introduce the concept of tendentious modernity, useful for studying transitional societies where modernity is a trend which coexists with obsolete institutional forms and ancient substance. Since it has no clear dominant form, it is considered to be mosaic modernity. Then I synthetically approach the process of Europeanization in the context of tendentious modernity. I start with the premise that Europeanization touches all sectors of a society in the EU. The new member states may be different in terms of their history, and, on the whole, are much different from the older EU members. Europeanization is part of tendentious modernity, at least for the recent members of EU.

In the second part, I examine mass media in societies experiencing tendentious modernity, with an emphasis on Romania. My thesis is that mass media could play an active role in promoting the European integration process if they move from reflecting historical particularities to reflecting the modern evolution of each EU member. Mass media promote this mosaic modernity, and they are the primary messenger of modernity and Europeanization.

\section{Tendentious modernity}

Modernization influences and affects all social and political changes that occur during industrialization, urbanization, occupational structures, social mobility, education development and political activity. Modernization includes cumulative processes which strengthen reciprocally: molding of capital, resources mobilization, development of production forces, growth of work productivity, central power and supporting national identities, the extension of political rights and social participation (Habermas, 2000, p. 20). 
Modernization, the process of deep change that influences all sectors of a society, first took place in Western Europe (Eisenstadt, 2003). During that time the evolution pattern had become one of social development, and was exported in areas with different economic, historical and social conditions. The modernization of Western countries has been a long historical succession of institutional construction and activity in public space, a process which has been assumed by the society's most prominent actors. Modernity has touched all social, cultural and institutional bottom structures. The middle class in the West has always promoted modern development along with its effects throughout their society.

However, modernity occurred differently in non-Western European countries. Due to either by external pressure, internal impulse or a mixture of the two, changes come about much differently than in the West. Because it has been imposed as a new evolutionary paradigm, the Western pattern of development has met the resistance of internal cultural patterns. Indisputably, society's modern evolution has not followed a unique modernity pattern. There are as many as there are societies.

Because of historical particularities, modern evolution in non-Western societies has begun with political institutional construction and not with the building of capitalist economy. I think it is useful to analyze the nonWestern modernization processes under the notion of 'tendentious modernity'. This means development in the opposite direction: from the affirmation of the national spirit and political construction towards economic development (Schifirneț, 2007b, p. 135; 2007c, p. 246). These societies have experienced late modernization; in the same time they have got many elements of modernity which fail to coagulate stable modern structures in all layers of society.

A key factor that distinguishes tendentious modernity societies in Eastern Europe from each other is their historical contexts: economic weakness, self-image as countries lying at the periphery of the West European center, authoritarian ruling for some decades.

In a tendentious modernity society, modernity is a trend, which coexists with obsolete institutional forms and ancient substance. Tendentious modernity penetrates slowly and scarcely through the complicated network of socioinstitutional structures of the traditional, patriarchal society. It is mosaic modernity that is not organized in a clear dominant form. Modernity is the framework and the main element that supports the nation, but not by means of economy, as the basis of a national state. Modernity is a tendency, an ideal in the construction of a nation. 
All anomalies, contradictions, or discrepancies that have arisen from the modernization process are considered typical phenomena for the new capitalist trend, because of its partial development. Accordingly, we can explain the existence of tendentious capitalism or partial capitalism, as being deprived from the economic mechanisms of capitalism, or performance, competition and profitability. Native modernization hasn't been the effect of an articulate application of a development project, but more an adaptation for seizing the opportunities of the moment.

For instance, Romania is a model for a country with incomplete transition. In its history, Romanian society has experienced a succession of transitions, because it has been forced to permanently solve new internal and external challenges. The ruling classes have been interested in filling in the gap with the modern Western countries, rather than in tracing directions of development as a historical continuity of local substance. This has happened because the western model has been too attractive and if it had been avoided or abandoned, it would have created incalculable results for the future of the Romanian society.

The fundamental problem of tendentious modernity is the degree and level of modernity spread in a society. In countries with tendentious modernity, only part of minority groups, of elites, supports the values of modernity and take advantage of them. In return, the larger population is only superficially touched by modernity and continues to live in the spirit of ancient values.

One more reason for developing the concept of tendentious modernity is the degree of democratization of inter-human and social relations, of citizensauthorities relationships. The fundamental difference between countries with consolidated democracy and other countries lies in the content, principles and methods of democracy. For instance, Romania has all necessary regulations in order to make democratic society work, but it does not function as a consolidated democracy. The concept of tendentious modernity expresses the fact that the law exists, but it is not applied or, if applied, it follows private or group interests. In societies with tendentious modernity the modernization rate is slower than in countries with consolidated modernity in what concerns the observance of rules, norms and laws by all social actors in all sectors of society.

Tendentious modernity exists in societies that avoid or postpone taking capitalism-related risks. Values characterizing the capitalist system: with strong convictions such as state intervention in economy and with high adversity towards risks (www.gallup.ro). 
There are discrepancies between the convictions of the population and of the political elite that, more than any other social supports the values of capitalism. This leads to the conclusion that a significant part of the population does not adhere to the ideologies promoted by the political parties in Romania. This is an indisputable argument for the top-down capitalist modernization, a clear expression of tendentious modernity.

\section{Europeanization and tendentious modernity}

The concept of tendentious modernity is useful in explaining Europeanization within the EU.

The adhering to the EU must be accompanied by the Europeanization of the new entity's whole space, which amounts to a new modernity. European countries experience three types of modernity: organic, tendentious and European modernity. The first took place in the West. Tendentious modernity is characteristic to Southern and Eastern Europe, and there are studies talking about the European periphery of Southern and Eastern Europe (Hatzaras, Dalakiouridou, 2006).

Within the EU, modernization takes place as the form of Europeanization. The effects of Europeanization are visible in domestic policies, structures, norms, state-society relations, and domestic constitutions in Europe. There are many faces of Europeanization (Olsen, 2002). Europeanization influences national societies directly or indirectly. For instance, Europeanization is not built by following exclusively a Bruxelles plan, but by answering local requests of each EU country.

A distinction must be made between Direct Europeanization, the intended impact of an EU initiative, and Indirect Europeanization, the inadvertent impact of an EU initiative, between Voluntary Europeanization and Coercive Europeanization. Voluntary-direct Europeanization is the ready adoption of EU decisions in a given area; Voluntary-indirect Europeanization refers to the adoption of EU preferences and/or practices and/or policies in another area. Coercive-direct Europeanization refers to the forced acceptance of European preferences and/or practices and/or policies in a given area, while Coercive-indirect Europeanization refers to consequences of Coercive-direct Europeanization in one area to another (Bache; Marshall, 2004). Coercive Europeanization implies forced or spontaneous institutional change in EU societies, and that is the reason why we consider that it can be read as tendentious modernity. 
Consequently EU is within the project of building an identity and a new European institutional framework. The EU as a whole experiences new developmental directions, which are distinct from the organic modernity of the Western countries.

Countries with consolidated democracies have an Europeanization deficit and local constraints lead to limits of Europeanization. The national policies are shaped and changed due to European integration (Featherstone; Radaelli, 2003, p. 5).

Undoubtedly, these limits are determined by tendentious modernity, a reality which explains Europeanization in a variety of local contexts of capitalism evolution. Although Europeanization policies have been developed at EU-level, they have generally followed top-down procedures of implementing legislative and administrative measures. These policies have not so far considered that Europeanization is largely a process determined by internal cultural patterns of societies.

Even the political discourse of each European country is slow in emphasizing the conscience of the European identity. According to a quantitative content analysis of the political discourses in quality newspapers (3,000 articles) of five EU member states (Austria, Denmark, France, Germany, Great Britain), the main pattern of trans-nationalization to be found in all countries is segmented Europeanization. The researchers find within each public sphere weak indications of a gradually developing European "we"-perspective, but neither a common discourse in Europe, nor a significant sense of belonging to the same community of communication does develop (Brüggemann at al., 2006, p. 25).

The citizens in recently integrated EU countries are still shaped by their own history and social world, which continues to forward mentalities and behaviors that are not compatible with European culture of modernity. Tendentious modernity is quite exact at expressing the duality of thought and action in recently integrated EU countries. Institutional transformations at European level can take place top-down, but modernization of society leads to Europeanization only if it is embedded in the everyday life of each individual and social group. Tendentious modernity is produced as top-down change, from the minority educated in the spirit of modernity and focused on modern transformations, to a majority that is indifferent or hostile to change. European modernity harmonizes the principles and norms of institutions' rationality with individual and group behaviors. We have in view the depth of modernity within a society, which means spontaneous, organic adhesion of all categories of population to the same values, behaviors, and ways of thinking and modern life-styles. 


\section{Mass media in tendentious modernity society}

Before analyzing the implications of tendentious modernity regarding mass media impact on society, we must remind that sociological studies underline the strong connection between mass media and the national construction. A nation's image owes largely to television (Castelló, 2007). It emphasizes that mass media have always been the school of the nation that forms the unitary national public (Anderson 1991). Although there is increasing fragmentation of media spheres, mass media continue to guarantee the symbolic integration of the nation as a community of communication (Trenz, 2008).

A. Giddens (1991) analyzes the role of mass media in modern society. He argues that modern society is characterized by time-space distanting and disembedding mechanisms. Thompson (1995, p. 38) says that mass media have reordered time and space within modern society. The influence of mass media can be explained through the evolution of society and values that characterize its different development stages. Mass media are a result of modernity, but in the same time they produce and spread modernity. Mass media have become both the cause and outcome of modern society, but the transition to postmodern society has changed the role of mass media (Ten Eyck, 2000).

\section{The impact of tendentious modernity on mass media}

In societies with consolidated modernity mass media are essential as a means of preserving social cohesion. In fact, they have had a decisive contribution to transmitting the same values and behaviors in a national state and have been a powerful force behind national cohesion. The independence of mass media is a fundamental direction of Europeanization.

The study on countries like Spain and Greece (Papatheodorou; Machin, 2003 , p. 32) reveals a pattern of mass media evolution determined by the association between political power and media organizations, which is utterly different from the Western one. Paternalism has been the determining factor in mass media evolution in the two countries. The same feature distinguishes ex-Communist European countries, which have gone from mass media dependence on the state in the Communist period to subordination to political forces and parties. 'As a result, the market of Polish press has come to be dominated by politically affiliated journalism pretending to be objective. This thing has become evident during electoral campaigns' (Jakubowicz, 1996, p. 205), an assertion which is true of mass media in Romania, as well. 
Formally, mass media are independent, but in reality the functioning of mass media is often affected by group interests. For instance, in the local elections in June 2008 in Romania mass media's expertise on some candidates' chances failed. Many of the candidates of whom media disapproved won. Mass media did not reflect correctly the options of the electorate, although polls indicated them. Mass media were forced to answer group interests, thus altering their independence. This independence is neither asserted in presenting and supporting European institutions nor in their significant presence in the European public sphere.

Europeanization as modernization is produced in the process of autonomous learning through a variety of means, mass media being some of the most prominent. They can influence top-down mentality changes and present those European initiatives, actions and behaviors built from bottom up: 'Rather we can see that perceptions and persuasions were incrementally changed by way of learning, due to a policy discourse, in which the European Commission played a major role' (Töller, 2004). Mass media are an intermediary factor between institutional norms and their form in daily behaviors. The influence of mass media in the Europeanization process is produced against the background of local social rationality which is different from, or even opposite to the one requested by Europeanization. There are internal cultural patterns which impact strongly on mass media. The options and mentalities on mass media are especially rooted in stable socio-cultural contexts offering (mainly through school) explanatory patterns and standardized knowledge for daily life and also solution patterns answering the individual interests and the values of the individual's group.

Mass media have a role in the Europeanization of democratic societies due to the presentation of principles and values of democracy. A society's Europeanization is a process taking place in democratic countries, where democracy means taking decisions based on norms and laws acknowledged in the public space. Mass media are in the same time a barometer of public opinion on perceiving Europeanization processes, on deciding how and to what degree Europeanization is a principle of the internal functioning of society, and of the construction of a European public sphere.

In a society where democracy is still being consolidated and institutions rather asnwer exterior pressures, as the ones made by mass media, their role can be negative.

The audiovisual behavior in the former socialist countries in Eastern Europe can be explained as a consequence of the inherited historical and cultural background, defined as a mosaic of premodernism, modernism and postmodernism. 
The studies find a positive, contemporaneous relationship between media liberalization and democratization. Media seem to play an important role in the process of democratization, and democracy similarly underlies media liberalization (Josh Pasek, 2006). Researchers discuss about the ambivalent interrelation between media and democracy: democracy enhancing and dumbing down. Media contribute either to the enhancement or to the dumbing down of democracy (Trenz, 2006).

In the post-communist period the research has underlined the contributions or failures of mass media in creating a new public space, in shaping public opinion and in changing mentalities. The reached conclusion was that mass media's failure to create civil society, the contradiction between the ideal pattern of public space and the reality in post-communist societies being all the more visible (Comşa et al., 2006, p. 34; Coman, 2003, p. 49).

Can mass media answer the Europeanization needs of all people in the EU countries? It is evident that mass media alone cannot produce Europeanization. They act within social and national contexts. They cannot modernize a society by themselves; they reflect what happens in a society. They can just constantly support groups that promote modernity, based on a program.

An expression of tendentious modernity is the over-emphasis of mass media functions and influence in society. In tendentious modernity mass media exceed their functions. They assume missions that belong to other institutions, but are also stimulated or forced to surpass their competences. They are transferred responsibility for objectives and behaviors that normally belong to other institutions. The reason why they are invested with other roles is mass media's higher degree of credibility compared to other institutions, a thing which becomes evident in the way they influence the public's ideas and behavior concerning the society's functioning and organization. Contrary to organic modernity societies where mass media's functions derive from institutional transformations, in tendentious modernity society's mass media are overloaded with a variety of functions, starting from information to solving citizens' problems.

An example of mass media overload is represented by the project adopted by the Romanian Senate modifying and completing the Audiovisual Law 504/2002, which requires the TV and radio stations to broadcast equal shares of positive and negative news. The purpose of this legislative proposal is 'to improve the general climate and offer the public the chance to balanced views on daily life, psychologically and emotionally' (Romanian Mediafax News Agency, 25-th June 2008). 
According to the authors of the law project, specialty studies highlight beyond doubt that the frequency of chronic diseases as a result of depressive mental states caused by negative news has increased. A transfer from the public to the private sphere is taking place nowadays through mass media. Society no longer has the instruments for solving many conflicts resulting from social or inter-human relations. This mission has been taken over by the media, especially television. Indeed, it is not rare that we watch medical diagnosis being made or treatment prescribed live on TV by less competent people who rarely mention precautions. Lately there has been a lot of talk about "telejustice", substituting real justice in Court.

Bringing regular people on the TV set, who practically 'make the show', leads to deep changes in the public space. So far the viewer would watch shows made by professionals, now he is lured into watching a show supposedly created by people like himself. Competence and qualifications no longer matter. Everything is spontaneous and intuitive.

Romanian mass media act within a society with a large share of rural population. Despite this, in Romania there is no TV station for the rural areas, although there are some folklore channels (Favorit, Ethno). The village is both perceived and addressed only through the folklore inheritance, which is not necessarily presented with its true values. Still, there is a radio station, Antena satelor (Villages' Antenna), with programmes targeted at the village public.

The media debase public discourse in village-like disputes between countrywomen. It is not far from the truth to say that Romanian mass media promote 'national gossiping' as a form of filling the public space by any means, but locking any rational arguments, and in disrespect for others' opinions.

Media and television especially do not answer the public's priorities and do not start from a certain category of public. The TV stations in Romania cannot claim a certain public, but certain sociological coordinates of the public. The rating does not target a specialized or a public of specific nature, but the audience, which is essential for selling advertising.

Because of market pressure and focus of media owners on maximum profit, mass media in Romania experience a quality crisis. In a society in transition like Romania, there is still no consolidated media market that would work exclusively on the principles of competition and quality. The process is slightly different from what happens in countries with tradition in mass media: instead of focusing on the public that requests a certain quality of media, articles or formats are addressed to a public interested in news and events with predominantly emotional impact or direct implications on daily life. A tabloidlike approach by all mass media, including the Internet. 
It is true that mass media build a new environment, 'the electronic reality', made up of images and symbols. Jean Baudrillard's hyper-real is the world generated by simulation, where the boundaries between the imaginary and the reality, between truth and falsehood disappear.

A thing expressed by the state of mass media in societies with tendentious modernity is that they take over TV formats from the West without adapting them to the market reality, due to their main purpose being to obtain a large audience. In tendentious modernity societies little attention is paid to research and knowledge of the cultural and social contexts where local mass media work. That is the reason why foreign TV formats are taken over without prior analysis, because they bring along profit and audience. The Romanian managers and journalists think that a product from another culture, be it inferior, can be equally efficient in another culture. They act by virtue of what Pierre Bourdieu (1999) calls the logic of the audience, a logic of demand and offer, a move of an economic equation in a media context.

$90 \%$ of TV formats are imported. Most come from the Netherlands, Great Britain, Sweden or Germany. Imported formats should have in view Romania's market and mentalities. The quality of educational influences of these formats is not discussed; rather encourage the appetite of the Romanian press for morbid stories.

Thus, derived formats are sometimes created, attempting to obtain the same success as the original show. Such imported shows in Romania are 'Suprises, surprises', 'Big Brother', 'The Geniuses', 'Who Wants to Be a Millionaire', 'Betrayed in Love', 'Forgive Me!”, 'Ciao, Darwin!', 'The Idiots', 'First Love', 'Mother Exchange', 'Super Nanny'. These shows are offered to the local public in the format taken over from the foreign stations. Although the first condition for a Western show to be broadcast on a Romanian channel is to be adapted to the national particularities, this thing is most often either ommitted, or totally neglected.

The ultimate purpose seems to be the profit obtained from broadcasting these formats. The Romanian cultural context and the Romanian public's media experiences are ignored. The public's expectations are thus not answered.

Specialists have appreciated that the failure of Big Brother in the last years has been a consequence of its not being at all adapted to the requests of the Romanian public, who was not prepared to see a reality show. The imported formats' lack of adaptability to the local context and the tendency of perpetual synchronization generate dysfunctionalities in the local media space, related to the gap between the public's real social world and the imported TV formats. 
A proof of tendentious modernity is offered by the brands' continuity of newspapers and magazines. Contrary to other cultures like Italy, for instance, where the newspaper Corriere della Sera has been issued without interruptions for more than a hundred years, Romania has no such newspapers. For instance, the issue of Adevărul (The Truth), established in 1888, one of the quality newspapers today, has been interrupted several times (longest in the Communist period, from 1952 to 1989). While in other ex-communist countries the official newspapers of former Communist parties continued to appear after 1989, for instance Népszabadság, in Hungary, in Romania the official paper of the Romanian Communist Party, Scânteia (The Sparkle), ceased the release on the night of December, 22, 1989. So did the newspaper The Youth's Sparkle, of the Young Communists' Union.

The national news agency constitutes another significant case. It was established by the communist regime as Agerpres, and after 1989 it changed its name in Rompres. In 2008 the Romanian Parliament adopted a law changing back the agency's name to Agerpres.

Although a lot of newspapers have appeared in Romania, there is still not a newspaper targeted specifically at the new public of the middle class, emerging after 1989. But there is no middle class public with a solid culture and clear-cut social and political interests.

The mass media public fluctuates. According to data from the National Audience Study (NAS), only $20 \%$ of a newspaper's audience are loyal (the same public reads the newspaper 5-6 times a week). The rest of $80 \%$ are the fluctuating public, skipping from one newspaper to another. The migration can be explained through the insert (a book, a CD, a DVD) accompanying the newspaper on a certain day of the week. In this case, newspapers offer an extra-journalistic product and for this reason buyers only purchase the newspaper on that very day to get the insert.

In a country lacking the tradition of specialized journalistic education media faces the consequences. Most TV journalists are not graduates of specialized studies but of other colleges, especially technical ones.

Romanian mass media have a dual attitude towards Europeanization. Journalists regard of the EU as another dimension of the media broadcast. Paradoxically, such a request does not result from the European traits of Romanian TV stations, because the European format is exactly what is missing. In this respect, tendentious modernity derives from the role of mass media in supporting a shallow or mosaic modernity, these idea is like Arjun Appadurai (1996) says that mass media promote this mosaic modernity. 
In reality, as we have previously said, mass media broadcast only the news that could bring audience, in their opinion. If Romanian TV stations were to broadcast accurate news that would inform the public about everything happening in society, it would amount to Europeanization.

Romanian mass media have already been going through an audience crisis, and getting over it forces them to go beyond the position of communication means in a society with tendentious modernity and to function at standards appropriate for a European country.

\section{Conclusions}

Mass media could play an active role in promoting the European integration process if they move from reflecting on historical particularities to reflecting on the modern evolution of each EU member. The concept of tendentious modernity, a useful tool for studying mass communication in the transition societies, is where modernization began with political institutional construction and not with the building of capitalist economy. Modernity is a trend, which coexists with obsolete institutional forms. Tendentious modernity penetrates slowly and with much difficulty through the complicated network of socio-institutional structures in traditional and patriarchal societies. Since it has no clear dominant form, it is mosaic modernity. Mass media promote this mosaic modernity, and they are the primary messenger of modernity and Europeanization.

\section{References}

ANDERSON, Benedict. Imagined communities: reflections on the origin and spread of nationalism. London; New York: Verso, 1991.

APPADURAI, Arjun. Modernity at large: cultural dimensions of globalization. Minneapolis: University of Minnesota Press, 1996.

BACHE, Ian; MARSHALL, Adam. Europeanisation and domestic change: a governance approach to institutional adaptation in Britain. Queen's Papers on Europeanisation from School of Politics, International Studies and Philosophy, Queen's University of Belfast. Online Papers, n. 5, 2004. Retrieved July 3, 2008 from http://ideas.repec.org/p/erp/queens/p0046.html.

BOURDIEU, Pierre. On television. Translated from the French by Priscilla Parkhurst. Ferguson: New Press, 1998.

BRÜGGEMANN, Michael et al. Segmented Europeanization: the transnationalization of public spheres in Europe - trends and patterns. (TranState Working Papers, 37) Bremen: Sfb 597, Paper 37, Bremen, URL: http://www.state.uni-bremen.de. 2006. Retrieved July 23, 2008 from http://www.bruegge.net/publikationen.php. 
CASTELLÓ, Enric. The production of television fiction and nation building: the Catalan case. European Journal of Communication, v. 22, n. 1, p. 49-68, 2007.

COMAN, Mihai. Mass media in România postcomunistă (Mass media in postcommunist Romania). Iaşi: Polirom, 2003.

COMŞA, Mircea et al. Barometrul de opinie publică: percepții despre mass media (Public opinion barometer: perceptions on mass media). Bucureşti: Fundaţia pentru o societate deschisă, 2006.

EISENSTADT, S. Comparative civilizations and multiple modernities: a collection of essays. Leiden: Brill, 2003.

FEATHERSTONE, Kevin; RADAELLI, Claudio M. (eds.). The politics of Europeanization. Oxford: Oxford University Press, 2003.

GIDDENS, Anthony. Modernity and self-identity: self and society in the late modern age. Cambridge: Polity Press, 1991.

HABERMAS, Jürgen. The structural transformation of the public sphere: an inquiry into a category of bourgeois society. Cambridge: MIT Press, 1989.

. Discursul filosofic al modernitătiii. (The philosophical discourse of modernity), translated in Romanian. Bucureşti: ALL, 2000.

HATZARAS, Kyriakos; DALAKIOURIDOU, Efpraxia. Economic modernization in the European periphery: the cases of Greece, Spain and Portugal. 2006. Retrieved July 20, 2008, from http://www.ideologikon.org.gr

JAKUBOWICZ, Karol. Post-communist media development in perspective. Bonn: Friedrich-Ebert-Stiftung, Internat. Internationale Politikanalyse Europäische Politik - Politikinformation Osteuropa, März, 2005.

OLSEN, Johan P. The many faces of Europeanization. Journal of Common Market Studies, Blackwell Publishing, v. 40, n. 5, p. 921-952, Dec., 2002.

PAPATHEODOROU, Fotini; MACHIN, David. The umbilical cord that was never cut: the post-dictorial intimacy between the political elite and the mass media in Greece and Spain. European Journal of Communication, v. 18, p. 31-54, 2003.

PASEK, Joshua. Fueling or following democracy? Analyzing the role of media liberalization in democratic transition. Paper presented at the annual meeting of the American Political Science Association, Aug. 31, 2006 Online. Retrieved July 7, 2008 from http://www.allacademic.com/meta/p152541_index.html.

SCHIFIRNET, Constantin. Tendentious modernity and Innovation. In: BÂRGĂOANU, Alina; PRICOPIE, Remus (eds.). Education, research and innovation. Bucureşti: Comunicare.ro, 2008. p. 385-390.

Mass media in national public sphere and in European public sphere. Romanian Journal of Sociology, p. 93-1001, 2007a.

From Romanian Indigenous Modernization to Europeanization. In: DOBRESCU, Paul; ȚĂRANU, Andrei; BÂRGĂOANU, Alina. (eds.). Proceedings of the globalization and policies of development: international conference 2007. May 17-19, 2007, Bucharest. Bucureşti: Editura Comunicare.ro, 2007b. p. 133-138. 
Formele fără fond, un brand românesc (The forms without substance, a Romanian brand). Bucureşti: Editura Comunicare.ro, 2007c.

TEN EYCK, Toby A. Interpersonal and mass communication: matters of trust and control. Current Research in Social Psychology, v. 5, n. 14, p. 206-224, 2000.

THE GALLUP Organization Romania. Capitalismul în mentalitățile românilor (Capitalism in Romanians' mentalities). 2006. Retrieved July 27, 2008:http://www. gallup.ro

THOMPSON, John B. The media and modernity: a social theory of the media. Cambridge: Polity; Stanford: Stanford University Press, 1995.

TÖLLER, Annette-Elisabeth. The Europeanization of public policies - understanding idiosyncratic mechanisms and contingent results. European Integration online Papers (EIoP). v. 8, n. 9, 2004. Retrieved July 7, 2008 from http://eiop.or.at/eiop/ texte/2004-000a.htm

TRENZ, Hans-Joerg. Mediatisation and democratization in the EU. Arena Working Paper Series: 14. Centre for European Studies, University of Oslo, 2006.

. In search of a European public sphere: Between normative overstretch and empirical disenchantment. Working Paper, n. 12, June, 2008. Retrieved July 20, 2008 from http://www.arena.uio.no/publications/working-papers2008/papers/wp08_12.

Received Jan. 09, 2009

Approved Apr. 29, 2009 